\title{
Potensi Energi Batubara serta Pemanfaatan dan Teknologinya di Indonesia Tahun 2020 - 2050 : Gasifikasi Batubara
}

\author{
Anugrah Pratama afin', Berkah Fajar Tamtomo Kiono² \\ ${ }^{1}$ Magister Energi, Sekolah Pascasarjana, Universitas Diponegoro; \\ 2Departemen Teknik Mesin, Fakultas Teknik, Universitas Diponegoro;
}

Email : anugrahpratamaafin@students.undip.ac.id (A.P.A), fajarberkah10@lecturer.undip.ac.id (B.F.T.K);

\begin{abstract}
Abstrak : Sebagai salah satu sumber daya alam yang melimpah di Indonesia, Batubara berdasarkan data yang diperoleh dari Badan Geologi Kementerian ESDM, potensi dan cadangan batubara sebesar 186 miliar ton yang ada di Indonesia dimana 52 persen berada di Pulau Sumatera , 47 persen berada di Pulau Kalimantan dan 1 persen berada di Pulau lainnya. Pada saat ini pemanfaatan sumber energi batubara juga semakin meningkat seiring dengan menurunya produksi minyak bumi. Maka saat ini banyak Industri yang mulai mengalihkan focus energi nya ke Batubara. Dewasa ini pemakaian batubara yang terbanyak adalah pada sektor pembangkit listrik, pabrik semen dan industri lainnya dimana hampir separuh konsumsi batubara domestik dipergunakan sebagai bahan bakar pembangkit listrik. Pemanfaatan batubara juga akan semakin dominan dengan adanya kebijakan energi nasional sementara itu produksi energi fosil yang lain seperti minyak bumi dan gas bumi mengalami penurunan akibat cadangan yang semakin menipis ditambah pula dari data bauran energi nasional masih didominasi oleh bahan bakar minyak maka bukan tidak mungkin harganya akan terus semakin meningkat oleh karena itu dengan potensi batubara yang ada untuk mulai dilakukan subtitusi dan diversifikasi terhadap bahan bakar minyak dan gas bumi menjadi menarik dikarenakan masih besarnya potensi batubara di Indonesia. Adapun teknologi yang digunakan yaitu diantaranya gasifikasi dimana teknologi ini mulai gencar dimulai maka dalam tulisan ini dicoba meninjau perkembangan gasifikasi serta pemanfaatan teknologi, kapasitas dan kondisi saat ini yang ada di Indonesia.
\end{abstract}

Kata Kunci : Energi Fosil, Gasifikasi, Batubara

\section{Pendahuluan}

Indonesia merupakan salah satu produsen dan eksportir batubara terbesar di dunia. Berdasarkan informasi yang disampaikan oleh Kementerian Energi dan Sumber Daya Mineral Indonesia, cadangan batubara Indonesia diperkirakan habis kira-kira dalam 83 tahun mendatang apabila tingkat produksi saat ini terus dilakukan. Sekitar 60 persen dari cadangan batubara total Indonesia terdiri dari batubara kualitas rendah yang lebih murah yang memiliki kandungan kurang dari $6.100 \mathrm{kal} / \mathrm{gram}$. Oleh karena itu, jenis batubara ini dijual dengan harga kompetitif di pasar internasional. Disisi lain, batubara 
dengan kualitas rendah juga dapat dimanfaatkan untuk menciptakan program hilirisasi batubara guna menganalisis potensi dan menciptakan diversifikasi batu bara sebagai Energi Alternatif.

Dirjen Industri Kimia, Tekstil dan Aneka Kemenprin (2017) memaparkan bahwa batubaru dengan kualitas rendah dapat dikembangkan untuk memproduksi gas dimetil eter (DME) yang bisa menggantikan liquefied petroleum gas (LPG) melalui proses gasifikasi batubara. Selain itu, Proses gasifikasi memiliki potensi yang cukup besar untuk membantu cadangan devisa negara, yang mana DME dan methanol dapat mengurangi impor dan mensubstitusi BBM, BBG dan bahan industri kimia dasar. Dibandingkan dengan China yang telah lebih dahulu menggunakan teknologi gasifikasi, di Indonesia gasifikasi baru dimulai dikarenakan harga bahan bakar minyak yang semakin mahal akibat pembatasan subsidi (Sasongko et., al , 2011). Gasifikasi juga dapat digunakan sebagai salah satu energi alternatif untuk menghasilkan nilai tambah yang besar bagi industri dalam negeri, namun pada praktiknya peningkatan nilai tambah batubara di Indonesia belum sepenuhnya mencapai tahap komersil. Sejauh ini, coal upgrading dan pembuatan briket batubara lah yang masih menjadi primadona dalam tahap komersil.

Penelitian dan pengembangan yang berkaitan dengan proses gasifikasi batubara sudah sejak lama dilakukan. Sejumlah Lembaga di Indonesia yang aktif melakukannya diantara lain BPPT, Tekmira dan PLN. Umumnya, penelitian terdahulu terfokus pada pemanfaatan syngas untuk bahan bakar transportasi, bahan baku Amonia pada industry pupuk serta pemanfaatan syngs batubara sebagai umpan bahan bakar Fuel cell. Dalam mengembangkan dan menerapkan proses gasifikasi pada batubara di Indonesia, sejumlah kriteria perlu diperhatikan agar mampu bekerja secara optimum dan meningkatkan nilai tambah batubara. Oleh karena itu, peneliti bertujuan untuk menganalisis potensi pemanfaatan batubara melalui teknologi gasifikasi secara terperinci.

\section{Bauran Energi Primer}

Saat ini batubara cukup mendominasi dalam bauran energi primer karena dianggap paling ekonomis dengan pertimbangan leastcost terutama untuk kebutuhan energi primer pembangkit listrik. Pemanfaatan batubara domestik tumbuh cukup tinnggi hingga mencapai $12 \%$ per tahun. Walau demikian, realisasi produksi batubara untuk konsumsi dalam negeri masih jauh lebih rendah dibandingkan dengan nilai ekspornya yang mencapai 73\% pada tahun 2019. Mengingat hal tersebut, Pemerintah perlu mendorong tingkat konsumsi batubara dalam negeri guna mencapai target yang ditetapkan. Pemanfaatan batubara domestik saat ini tercatat untuk PLTU, industri semen, metalurgi, pupuk, tekstil, kertas dan briket. Dua konsumen terbesar adalah PLTU dan industri. Pemerintah juga perlu meningkatkan konsumsi batubara dalam negeri, tidak hanya sebagai bahan bakar namun juga dikembangkan untuk bahan baku industri. Sejauh ini Pemerintah telah memberikan kerangka regulasi terkait Peningkatan Nilai Tambah sebagaimana diatur dalam Permen ESDM No. 25 Tahun 2018 tentang Pengusahaan Pertambangan Mineral dan Batubara untuk meningkatkan konsumsi batubara dalam negeri, antara lain peningkatan mutu batubara; pembuatan briket batubara, pembuatan kokas, pencairan batubara, gasifikasi batubara termasuk underground coal gasification dan coal water mixture. Hilirisasi batubara selama ini masih terkendala teknologi dan keekonomiaan, karena sampai saat ini baru ada dua jenis skema hilirisasi yang berhasil dikembangkan dan dijalankan secara komersial yaitu :

1) Peningkatan mutu batubara

2) Briket batubara 
Hilirisasi batubara dengan skema yang lain seperti gasifikasi batubara perlu dikembangkan termasuk juga meninjau kebijakan insentif yang dapat diberikan untuk mendorong investor yang serius memanfaatkan peluang ini. Saat ini telah ada satu kilang swasta yang memproduksikan DME dari metanol untuk kebutuhan industri dengan kapasitas produksi hanya sebesar 12.000 ton/tahun. Di samping itu, pengembangan gasifikasi batubara telah dilakukan melalui konsorsium antara BUMN dengan pihak swasta di Peranap, Riau (kapasitas 1,4 juta ton/tahun) dan di Tanjung Enim, Sumatera Selatan (kapasitas $400 \mathrm{ribu}$ ton/tahun) untuk pembangunan pengolahan Dimethyl Ether (DME) sebagai bahan campuran LPG yang ditargetkan selesai pada tahun 2023. Kebijakan untuk mendorong peningkatan pemanfaatan batubara dalam negeri menjadi dilematik, karena kebijakan tersebut dapat menekan peran EBT dalam bauran energi primer nasional jika laju pemanfaatan EBT tidak sesuai dengan target, terutama pada pemanfaatan batubara di sektor kelistrikan sebagai energi primer.

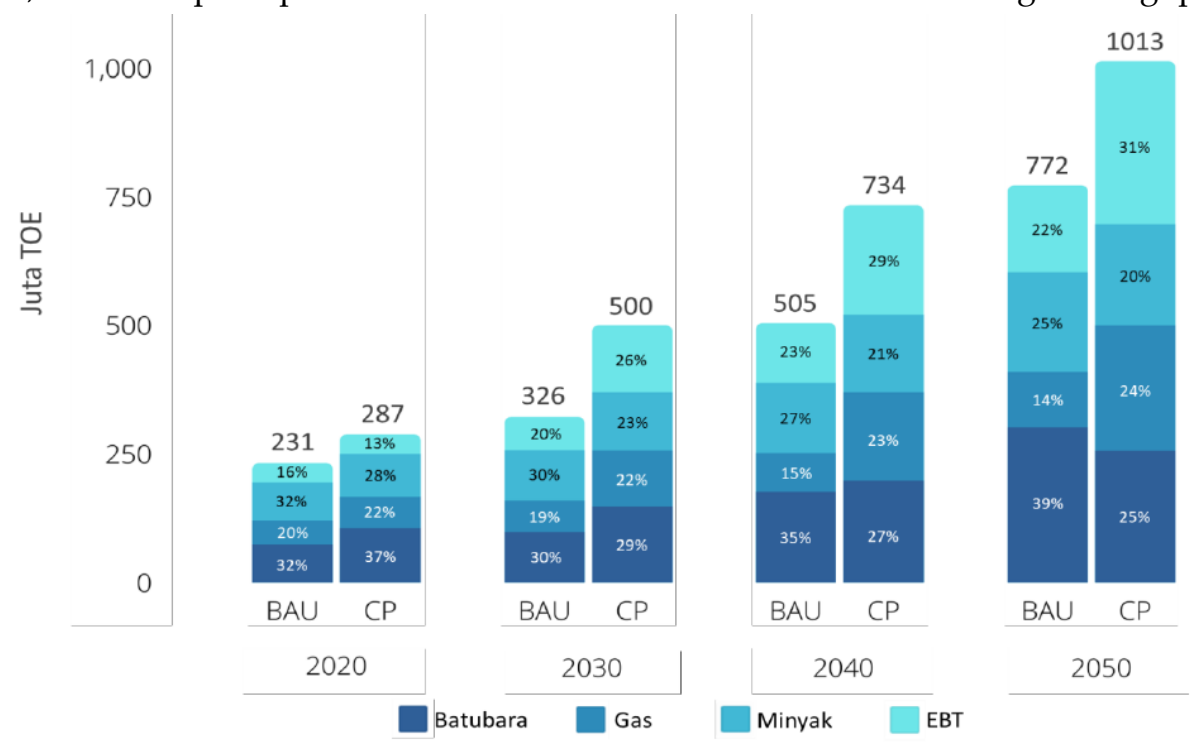

Gambar 1. Bauran Energi Primer (Sumber: RUEN, BPPT, 2020)

Energi fosil masih mendominasi penyediaan energi primer Indonesia hingga tahun 2050 dengan peningkatan selama periode proyeksi sebesar 407 juta ton oil equivalent (TOE) (BAU) dan 448 juta (CP). Meskipun nilai absolut energi fosil meningkat, pangsa energi fosil terhadap penyediaan energi primer total mengalami penurunan menjadi 88\% (BAU) dan 69\% (CP). Pangsa batubara diperkirakan terus menurun tapi perannya masih cukup tinggi hingga 2050. Hal ini dikarenakan ketergantungan penggunaan Batubara terutama pada sektor pembangkit masih cukup tinggi.

\section{Cadangan dan Produksi Batubara}

Indonesia merupakan salah satu negara produsen batubara di dunia, dengan sumber daya dan cadangan yang tersebar hampir diseluruh wilayah seperti ditunjukkan pada Gambar 2. Cadangan dab sumber daya Batubara Indonesia per tahun 2019 adalah sebesar 186,6 miliar Ton.

Potensi dan cadangan batubara nasional merupakan potensi yang masih tersimpan didalam bumi belum dimanfaatkan untuk tujuan komersil. Potensi yang dimaksud yaitu adalah potensi telah teridentifikasi awal jenis, jumlah, mutu dan lokasi serta potensi yang belum teridientifikasi jenism jumlahm mutu dan lokasi. Potensi terbesar batubara Indonesia terdapat di Pulau Sumatera dan Pulau Kalimantan. Sebagian potensi tersebut juga terdapat di Pulau Jawa, Pulau Sulawesi, Maluku dan 
Vol. 2, No. 2, pp $114-122$

doi: $10.14710 /$ jebt.2021.11429

Papua. Potensi batubara nasional berdasarkan jenis dan keterdapatannya, terdiri daru sumber daya sebesar 149.009,59 juta ton, cadangan sebesar 37.604,66 juta ton dan sumber daya tambang dalam (100500 meter) sebesar 43.250,11 Juta ton. Tambang dalam terdapat di sumatera selatan, Kalimantan timur, Kalimantan utara dan Kalimantan selatan dengan sumber daya sebesar 43.250,11 Juta Ton. Dari jumlah tersebut potensi di Sumatera sebesar 22.174,51 Juta ton dan Kalimantan sebesar 21.075,60 Juta ton.

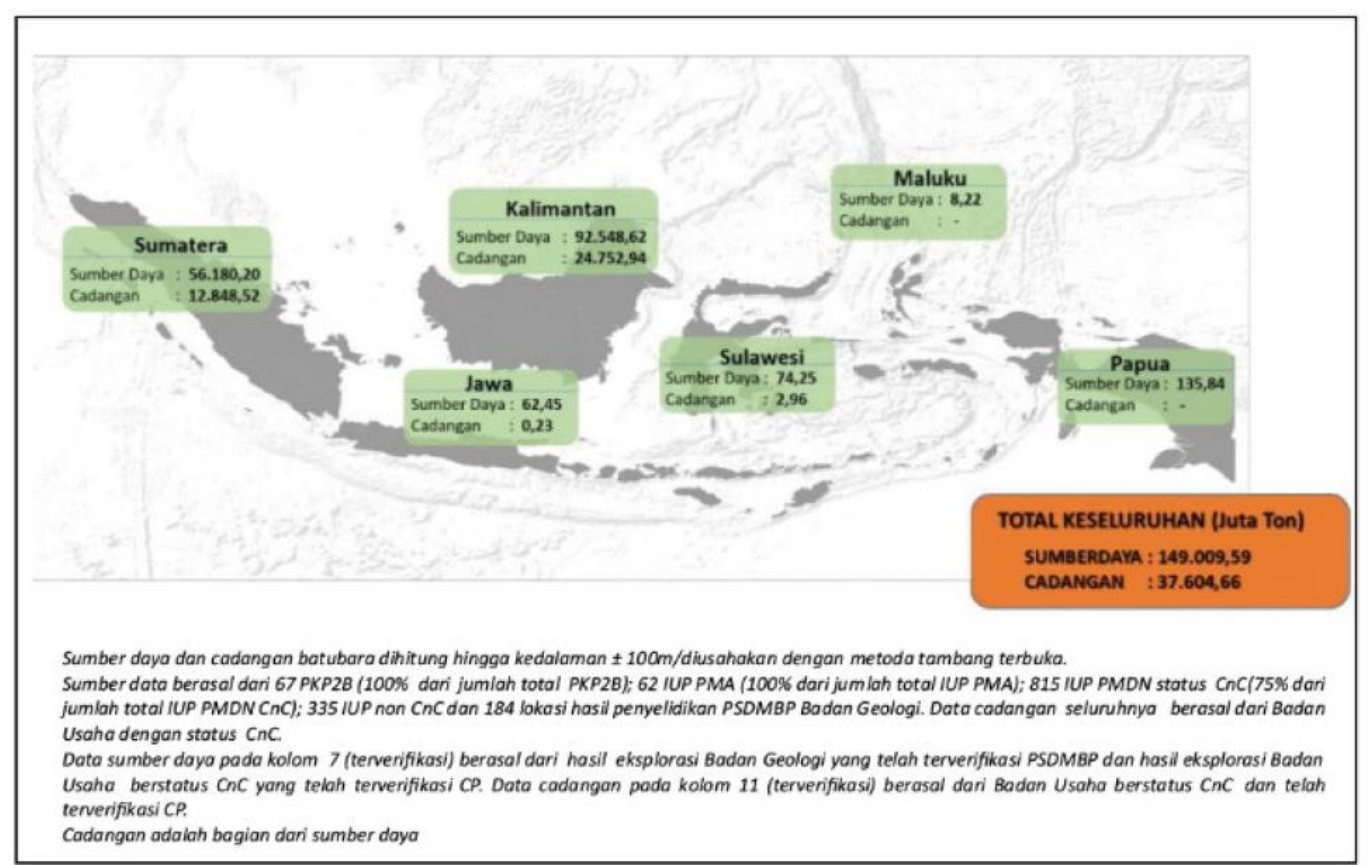

Gambar 2. Sumber Daya dan Cadangan Batubara Indonesia (Sumber: PSDMBP,2019)

Tabel 1.

Potensi Batubara Tambang Dalam (Sumber: PSDMBP,2019)

\begin{tabular}{lcc}
\hline \multicolumn{1}{c}{ Lokasi } & Jumlah (Juta Ton) & Mutu \\
\hline Sumatera : & $22.174,51$ & Kelas Kalori, \% Sulfur, \% Abu \\
Sumatera Selatan & & $\begin{array}{c}\text { dan \% Moisture sudah diketahui } \\
\text { Kalimantan : }\end{array}$ \\
Kalimantan Timur (83\%) & $21.075,60$ & $\begin{array}{c}\text { Kelas Kalori, \% Sulfur, \% Abu } \\
\text { dan \% Moisture sudah diketahui }\end{array}$ \\
Kalimantan Utara (12\%) & \\
Kalimantan Selatan (5\%) & \\
\hline
\end{tabular}

Secara umum cadangan batubara Indonesia saat ini sebesar 37.604,66 juta ton. Apabila dilakukan pengendalian produksi batubara sebesar 400 juta ton per tahun sebagaimana amanat RUEN, maka cadangan batubara Indonesia diperkirakan masih mencukupi hingga 97 tahun ke depan. Dengan realisasi produksi batubara tahun 2019 sebesar 616 juta ton, cadangan batubara Indonesia diperkirakan masih mencukupi hingga 71 tahun ke depan. Berdasarkan data Badan Geologi KESDM tahun 2019 total sumber daya batubara terverifikasi adalah 88,34 milyar ton dan cadangan batubara terverifikasi adalah 25.070,50 juta ton dimana total cadangan batubara nasional masih berada di kisaran 3-4\% dari cadangan batubara dunia dan menempati peringkat ke 9 dunia. 


\section{Infrastruktur dan Teknologi Pemanfaatan Batubara : Gasifikasi Batubara}

Gasifikasi adalah proses dimana batubara dapat diubah menjadi syngas $\left(\mathrm{CO}+\mathrm{H}_{2}\right)$, yang kemudian dapat digunakan untuk menghasilkan berbagai bahan kimia, baik secara langsung atau melalui perantara, seperti metanol. Biasanya, $1 \mathrm{~kg}$ batubara bituminus dapat diubah menjadi 1,5-1,7 $\mathrm{m}^{3}$ syngas. Rantai produk industri kimia batubara bisa sangat luas. Industri kimia batubara tradisional meliputi produksi amonia, kokas dan kalsium karbida. Pada saat yang sama, terutama di Cina, ada industri kimia batubara baru yang signifikan yang didirikan berdasarkan sistem gasifier modern, untuk produksi pupuk, hidrogen, pengganti petrokimia seperti etilen glikol, olefin dan SNG, bersama dengan bahan bakar transportasi, seperti ditunjukkan pada Gambar 3.

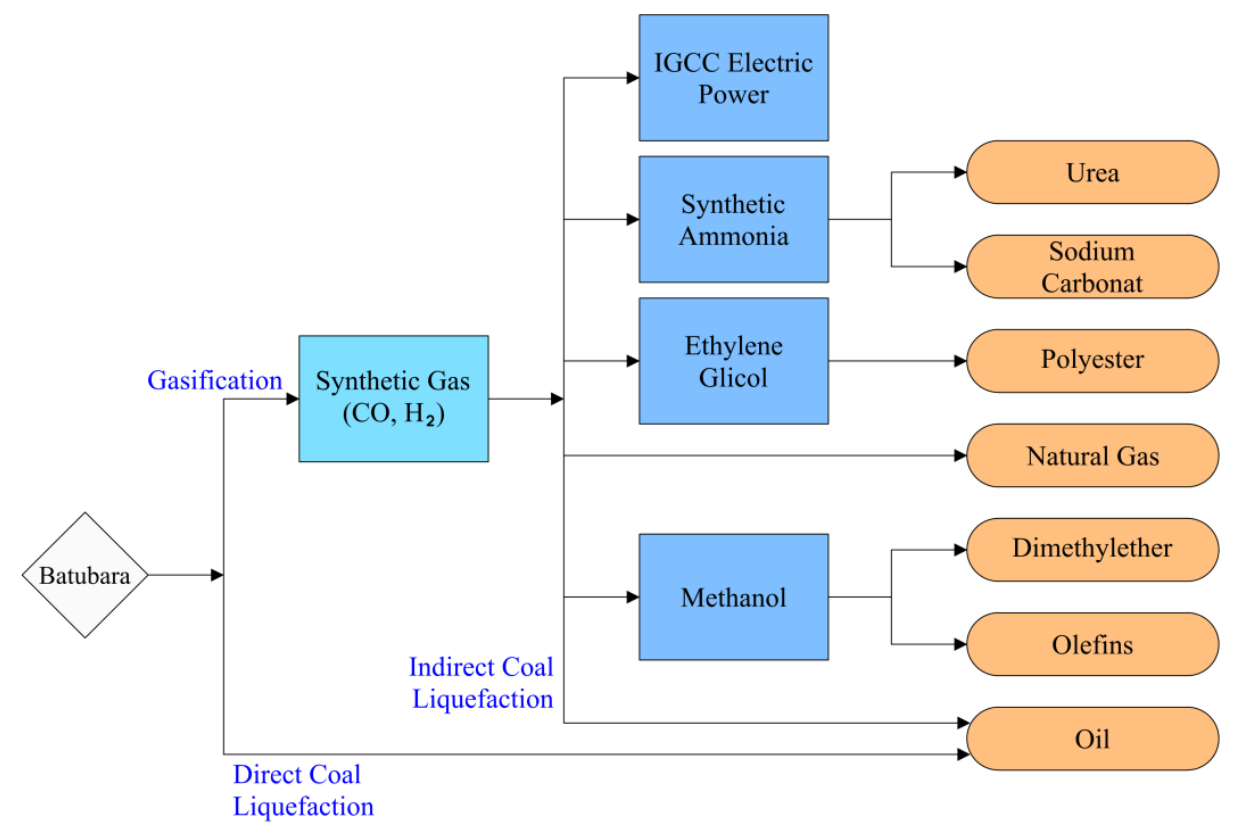

Gambar 3. Proses Gasifikasi Batubara (Sumber: seeking alpha,2012)

Dalam hal fleksibilitas bahan baku, beberapa desain pabrik gasifikasi telah dikembangkan untuk memanfaatkan berbagai kelas batubara selain limbah dan biomassa. Secara khusus, sistem gasifier modern ini menyediakan sarana untuk memonetisasi cadangan batubara yang besar dan berkualitas rendah, terutama lignit yang berada di dasar sistem penilaian batubara karena kandungan air dan abunya yang tinggi, dan dalam banyak kasus tidak dapat langsung digunakan untuk tujuan alternatif (Petroleum Economist, 2010). Gasifikasi menghasilkan emisi gas yang sangat rendah dari polutan konvensional (non GRK), karena sifat operasi proses. Ini juga menawarkan rute biaya marjinal yang berpotensi rendah untuk menangkap $\mathrm{CO}_{2}$ yang dihasilkan oleh produk baik untuk penyimpanan geologis atau pemulihan minyak yang ditingkatkan. Daya tarik potensial lebih lanjut adalah bahwa gasifikasi batubara untuk menghasilkan bahan bakar dan produk kimia dapat membantu membatasi kebutuhan impor gas alam dan minyak, sehingga menawarkan beberapa tingkat keamanan energi, terutama karena harga batubara umumnya cenderung kurang stabil dibandingkan bahan bakar fosil lainnya (Minchener, 2009). Dengan demikian biaya produk akhir harus cukup dapat diprediksi. Namun, sistem konversi batubara berbasis gasifikasi tersebut membutuhkan investasi modal awal yang signifikan, terutama proses batubara menjadi minyak. Hal ini dapat menimbulkan 
ketidakpastian keuangan karena harga sumber produk akhir yang bersaing, seperti minyak dan gas, bisa sangat fluktuatif. Selain itu, proses ini membutuhkan penggunaan air yang signifikan, yang di wilayah tertentu di dunia menjadi perhatian yang berkembang. Mereka juga bisa menjadi penghasil emisi $\mathrm{CO}_{2}$ yang besar. Tabel 2 menunjukkan konsumsi unit batubara dan air dalam unit produksi berbagai produk kimia utama, dan pelepasan $\mathrm{CO}_{2}$ sebagai produk sampingan, berdasarkan pengalaman yang ada saat ini di negara China.

Tabel 2.

Konsumsi Batubara dan Air Serta Pelepasan Emisi CO2 (Seeking Alpha, 2012; ICIS, 2013)

\begin{tabular}{lccc}
\hline \multicolumn{1}{c}{ Chinese Applications } & $\begin{array}{c}\text { Standard Coal } \\
\text { Consumption } \\
\text { (Tonnes/Tonnes) }\end{array}$ & $\begin{array}{c}\text { Water Consumption } \\
\text { (Tonnes/Tonnes) }\end{array}$ & $\begin{array}{c}\mathrm{CO}_{2} \text { Emissions } \\
\text { (Tonnes/Tonnes) }\end{array}$ \\
\hline Indirect Coal Liquefaction & 4,39 & 13 & 5,0 \\
Coal-to-Olefins & 6,68 & $15-20$ & 5,5 \\
Coal-to-Ethylene Glycol & 2,55 & 14 & 2,0 \\
Coal-to-SNG & 2,83 & 6,58 & 2,5 \\
\hline
\end{tabular}

\section{Tantangan Indonesia kedepan}

\subsection{Gasifikasi Batubara untuk Ketenagalistrikan}

Sebagaimana yang telah dituangkan PLN pada RUPTL 2015-2025 Untuk Sistem Sumatera, Produksi listrik tahun 2020 berdasarkan energi primer dalam scenario baseline sistem Sumatera adalah 60,2\% untuk batubara, 13,6\% untuk hidro, 10,1\% untuk panas bumi, 9,8\% untuk gas, 6,0\% untuk gasifikasi batubara dan hanya $0,2 \%$ untuk bahan bakar minyak. Total daya terpasang pada tahun 2020 direncanakan sebesar 400 MW melalui teknologi IGCC (Integrated Gasification Combined Cycle). Diperkirakan total investasi PLN untuk gasifikasi batubara di pembangkit listrik selama 10 tahun (2010-2019) adalah sebesar 414 juta US\$ untuk 207 MW PLTGB, sementara sisa target daya terpasang diharapkan dapat dibangun dengan investasi pihak swasta atau masyarakat.

\subsection{Gasifikasi Batubara untuk Industri Kimia}

$\mathrm{H}_{2}$ dan $\mathrm{CO}_{2}$ yang diperoleh dari gasifikasi dapat digunakan untuk berbagai tujuan seperti pembuatan amonia sebagai bahan baku Urea. Selama ini, bahan baku Amonia yaitu $\mathrm{H}_{2}$, dipenuhi dengan pasokan dalam kontrak jangka panjang yang diatur oleh pemerintah. Untuk memenuhi kebutuhan sektor pertanian yang terus meningkat diikuti dengan target pemerintah untuk merevitalisasi industri pupuk urea dari 8,05 juta ton/tahun menjadi 10,40 juta ton/tahun di tahun 2014, diperlukan sumber-sumber baru atau alternatif pemenuhan kebutuhan bahan baku Urea. Sejumlah industri pupuk di Indonesia menyatakan minatnya untuk membangun plant gasifikasi batubara guna menambah pasokan bahan baku utama pembuatan Urea, yaitu $\mathrm{H}_{2}$ dan $\mathrm{CO}_{2}$. PT PUSRI dan PT Pupuk KALTIM telah menjajaki sejumlah studi untuk kemungkinan penggunaan batubara kualitas rendah (low rank coal) digunakan sebagai feedstock. Kebutuhan batubara untuk pabrik Urea (termasuk kebutuhan pembangkit listrik pabrik) kapasitas 3.099 ton/hari (1.022.670 ton/tahun) membutuhkan batubara jenis sub-bituminous (kalori sekitar $4.250 \mathrm{kkal} / \mathrm{kg}$ ) untuk keperluan gasifikasi sebanyak 10.636 ton/hari (3.509.880 ton/tahun). Sehingga, jika total kapasitas terpasang pabrik pupuk Urea di Indonesia saat ini mencapai 8,05 juta ton, maka diperlukan sekitar 27,63 juta ton/tahun batubara sebagai bahan baku. 


\subsection{Gasifikasi Batubara untuk Pemanfaatan Thermal}

Teknologi gasifikasi dimanfaatkan oleh sejumlah Industri Steel Furnace dan Keramik di Indonesia. Sebagai contoh, Industri Keramik Sango di Semarang, memiliki 3 unit reaktor gasifikasi batubara untuk memenuhi kebutuhan gas pada proses pembakaran keramik. Saat ini tengah diselesaikan pembangunan reaktor gasifikasi ke 4 sehingga total menjadi sekitar 4,4 MW thermal.

\subsection{Gasifikasi Batubara untuk Bahan Bakar Cair}

Proses sintesis Fischer-Tropsch digunakan untuk mengubah syngas batubara menjadi liquid dengan bantuan katalis. Produk yang dihasilkan antara lain adalah methanol, bensin, naphtha dan diesel. Methanol sendiri kemudian dapat digunakan sebagai bahan baku pembuatan DME (Dimethyl Ether). Sejumlah rencana pembangunan plant DME dan bahan bakar cair lainnya saat ini tengah dikembangkan, antara lain dengan melakukan kajian kelayakan pembangunan plant menggunakan bahan baku batubara kualitas kalori rendah.

Bahan bakar transportasi (bensin/bensin, solar dan bahan bakar jet) saat ini berasal dari minyak mentah, yang memiliki kandungan hidrogen sekitar dua kali lipat dari batubara. Untuk batubara untuk menggantikan minyak, itu harus diubah menjadi cairan dengan kandungan hidrogen yang mirip dengan minyak dan dengan sifat yang serupa. Hal ini dapat dicapai baik dengan menghilangkan karbon atau dengan menambahkan hidrogen, sementara juga sebagian besar menghilangkan unsur-unsur seperti belerang, nitrogen dan oksigen (Williams dan Larson, 2003). Ada dua pendekatan untuk menyediakan bahan bakar cair dari batubara (Couch, 2008).

Dalam konversi langsung batu bara, biasanya disebut sebagai pencairan batu bara langsung (direct coal liquefaction, DCL), batu bara bubuk diperlakukan pada suhu dan tekanan tinggi dengan pelarut yang terdiri dari minyak daur ulang yang diturunkan dari proses, Gambar 4. Rasio hidrogen/karbon ditingkatkan dengan menambahkan gas $\mathrm{H}_{2}$ ke bubur batu bara dan cairan turunan batu bara, bersama dengan katalis untuk mempercepat reaksi yang diperlukan. Cairan yang dihasilkan memiliki struktur molekul yang mirip dengan yang ditemukan dalam senyawa aromatik dan perlu ditingkatkan lebih lanjut untuk menghasilkan bahan bakar spesifikasi seperti bensin/bensin dan bahan bakar minyak. Hasil cair lebih dari $70 \%$ berat umpan batubara bebas abu kering telah ditunjukkan untuk beberapa proses, meskipun dalam keadaan yang menguntungkan. Efisiensi termal keseluruhan untuk proses modern umumnya berkisar $60-70 \%$. Jalur pencairan batubara tidak langsung (ICL) adalah proses suhu tinggi, tekanan tinggi yang pertama-tama membutuhkan gasifikasi batubara untuk menghasilkan syngas, yang dapat diubah menjadi bahan bakar cair baik melalui proses FT atau proses Mobil (Radtke dkk, 2006). ). Dalam proses FT, yang lebih umum, syngas dibersihkan dari kotoran dan kemudian digabungkan/dibangun kembali secara katalitik untuk membuat cairan yang dapat disuling. Ini dapat mencakup bahan bakar hidrokarbon seperti bensin/bensin sintetis dan solar, dan/atau bahan bakar beroksigen, bersama dengan berbagai kemungkinan produk lainnya. Untuk tahap sintesis FT, pilihan pembuatan bensin atau solar ditentukan oleh pilihan suhu operasi dan pilihan katalis, Gambar 6. Dalam proses Mobil, syngas dapat diubah menjadi metanol, yang kemudian diubah menjadi produk minyak bumi melalui urutan dehidrasi (AAAS, 2009). 
Vol. 2, No. 2, pp $114-122$

doi: $10.14710 /$ jebt.2021.11429

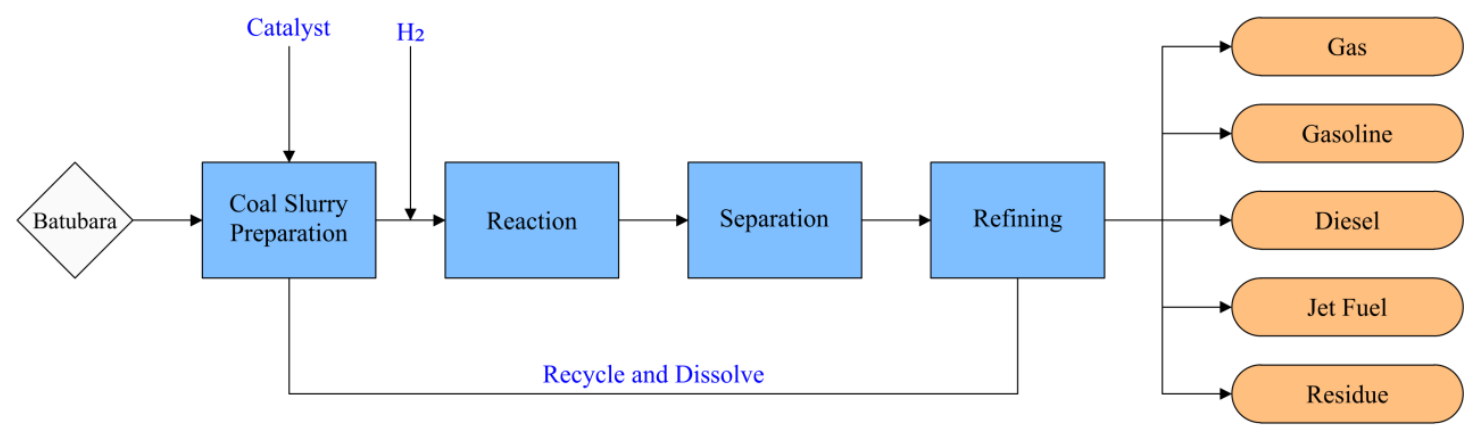

Gambar 4. Proses Sederhana Pencairan Batubara Langsung (Sumber: Deutsche Bank, 2012)

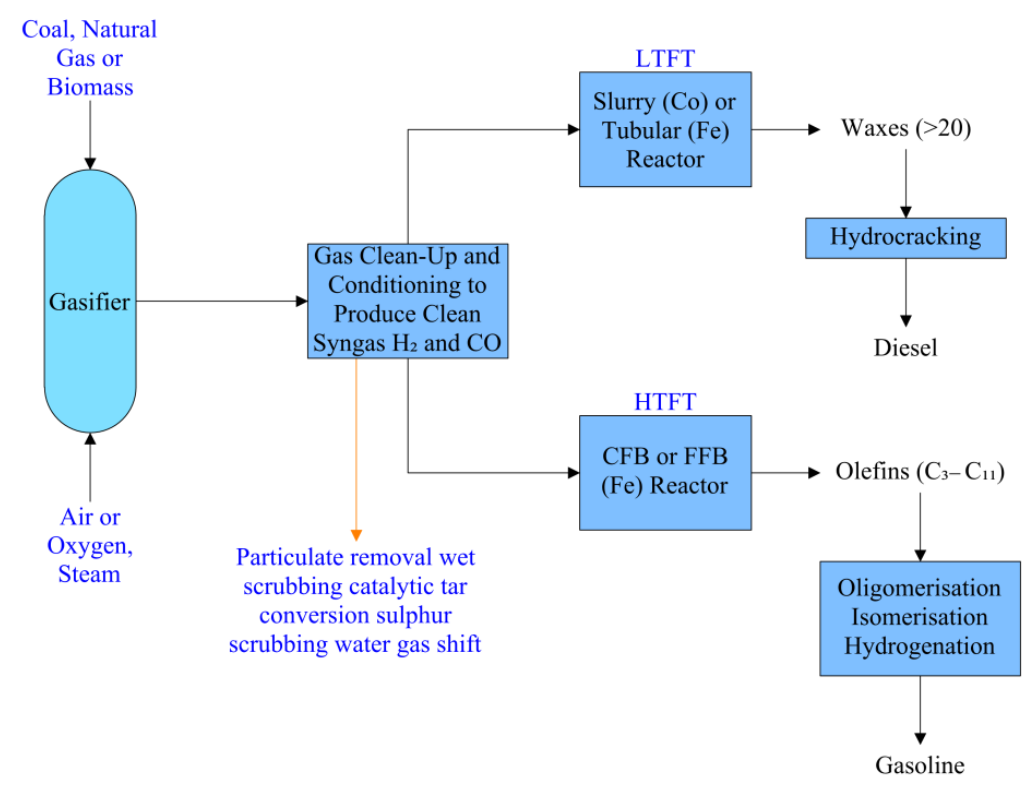

Gambar 5. Diagram Alir dari 2 Metoda Proses Bahan Bakar Sintetis menggunakan Prinsip Fischer-

Tropsch. (Sumber: Spath dan dayton, 2012)

\section{Kesimpulan}

Pemanfaatan teknologi gasifikasi batubara di Indonesia memiliki peluang yang cukup menjanjikan di berbagai sektor kebutuhan masyarakat seperti, industry petrokimia, pembangkit tenaga listrik dan pemanfaatan thermal. Penguatan penguasaan teknologi gasifikasi perlu ditingkatkan mengingat diproyeksikan peran gasifikasi batubara kedepan akan cukup besar karena jumlah cadangan energi fosil yang berasal dari batubara ini cukup melimpah di Indonesia dibandingkan dengan energi fosil lainnya. Jenis batubara di Indonesia yang didominasi oleh batubara kalori rendah memerlukan inovasi di dalam teknologi gasifikasi yang umumnya didesain untuk kalori menengah dan tinggi agar lebih efisien dan optimal. Teknologi gasifikasi batubara sangat baik diterapkan untuk daerah-daerah dengan pembangkit listrik skala kecil menengah dan masih mengkonsumsi BBM sebagai bahan bakarnya. Dengan model subtitusi bahan bakar tersebut, diharapkan dapat mengurangi secara signifikan ketergantungan terhadap BBM dan menghemat anggaran pemerintah dalam subsidi biaya produksi listrik di pembangkit. Pada akhirnya pemanfaatan secara optimal teknologi gasifikasi batubara yang ada akan mendukung pembangunan kemandirian energi bangsa dari impor bahan bakar. 


\section{Daftar Pustaka}

Dewan Energi Nasional. (2019). Bauran Energi Nasional 2019. Jakarta: Sekretaris Jenderal Dewan Energi Nasional.

Dewan Energi Nasional. (2020). Bauran Energi Nasional. Jakarta: Sekretaris Jenderal Dewan Energi Nasional.

Internasional Energi Agency (IEA). (2021, Mei 4). World Energy Outlook 2020. Retrieved from Internasional Energi Agency (IEA): https://www.iea.org

Kementerian Energi dan Sumber Daya Mineral (KESDM). (2020). Ringkasan Renstra 2020-2024. Jakarta: Kementerian Energi dan Sumber Daya Mineral.

Kementerian Energi dan Sumber Daya Mineral (KESDM). (2021, Mei 5). Kementerian Energi dan Sumber Daya Mineral. Retrieved from Direktorat Jenderal Energi Baru, Terbarukan dan Konservasi Energi: https://ebtke.esdm.go.id

Khan, H., Khan, I., \& Binh, T. T. (2020). The heterogeneity of renewable energy consumption, carbon emission and financial development in the globe: A panel quantile regression approach. Energy Reports, 859-867.

Luo, C., \& Wu, D. (2016). Environment and economic risk: An analysis of carbon emission market and portfolio management. Environmental Research, 297-301.

Pusat Pengkajian Industri Proses dan Energi, \& Badan Pengkajian dan Penerapan Teknologi. (2020). Outlook Energi Indonesia 2020. Jakarta: PPIPE \& BPPT.

Republik Indonesia. (2014). Peraturan Pemerintah No. 79 Tahun 2014 tentang Kebijakan Energi Nasional. Jakarta: Sekretariat Negara Republik Indonesia.

Republik Indonesia. (2017). Peraturan Presiden No 22 Tahun 2017 tentang Rencana Umum Energi Nasional. Jakarta: Sekretariat Negara Republik Indonesia.

Santika, W., Anisuzzaman, A., Simsek, Y., Bahri, P., Shafiullah, G., \& Urmee, T. (2020). Implications of the Sustainable Development Goals on national energy. Energy.

Wang, J., Zhang, S., \& Zhang, Q. (2021). The relationship of renewable energy consumption to financial development and economic growth in China. Renewable Energy, 897-904. 